\title{
Modeling and Analysis of Optimal Selection of Ideological and Political Education in Colleges and Universities
}

\author{
Yong Li \\ Zaozhuang Vocational College of Science \& Technology, Tengzhou, Shandong, 277599, China
}

Keywords: ideological and political education; spiritual civilization construction; teaching methods

\begin{abstract}
In order to improve the quality of ideological and political education in colleges and universities, ideological and political education is not only the primary content of China's spiritual civilization construction, but also one of the main ways to solve social contradictions and problems. The selection model of ideological and political education in colleges and universities is divided into active education mode, passive education mode and vocational education mode. This paper analyzes the problems existing in ideological and political education in colleges and universities, analyzes the effectiveness of ideological and political education mode by combining the teaching-driven mode, and optimizes the selection of ideological and political education models. Let the whole society attach importance to the ideological and moral construction of the society, deepen the ideological and political work from the perspective of personality and human psychology, so that ideological and political work can form a daily and subtle effect, and through ideological and political education, it makes college students form correct ideological behavior, promote the cooperation of society, school and family, and improve the ideological and political quality of college students.
\end{abstract}

\section{Introduction}

The Party and the government have always attached importance to the education and training of college students' ideological renovation. The great rejuvenation of the Chinese nation lies in the younger generation. The competition in the future world is actually the competition of the youth, and talent competition, ideological and political education is responsible for shaping the soul of young students. At present, colleges and universities in the country have set up courses of ideological and political education for their students, and have arranged a large number of hours, and the contents are also quite rich ${ }^{[1]}$. Overall, with the active efforts and continuous exploration of the vast number of educators, great achievements have been made in the ideological and political education work in colleges and universities. Ideological and political education means that the society or social groups use certain ideological concepts, political views, moral norms, and impose purposeful and planned measures on their members. The organized teaching method is researched, through ideological and political education in colleges and universities, it enables college students to form the ideological and moral character which meets the needs of certain society, and forms the ideological and moral standard. With the development of the reform of moral education and ideological and political education curriculum system in colleges and universities, the value of ideological and political education is becoming more and more obvious. The classroom of ideological and political education is the main classroom to cultivate the ideal, belief and moral character of college students in the new era. It plays an important role in building the spiritual civilization system and moral civilization system of socialism with Chinese characteristics. Through the classroom education of ideological and political education in colleges and universities, we can cultivate the correct outlook on life, values and world outlook of college students. The theory of socialism with Chinese characteristics in the new era is learned, learning and mastering the policies, principles and lines of the Party, standing at a new historical starting point, the classroom of ideological and political education conforms to the trend of history, it plays an important role in cultivating the moral construction of college students and the construction of socialist spiritual civilization in the new era ${ }^{[2]}$. 
General Secretary Xi Jinping stressed: "In order to make good use of the main channel of classroom teaching, the ideological and political theory course should be strengthened in the course of improvement." "All other courses should keep a section of canal and cultivate a good field of responsibility, so that all kinds of courses and ideological and political theory courses go in the same direction and form a synergistic effect.” Ideological and political education is the foundation of all kinds of professional curriculum education in college classroom. Through ideological and political education, it can set up correct values and civilization for college students. Ideological and political education classroom plays an important role in socialist ideal and belief education and the construction of spiritual civilization system. As a basic content of college students' curriculum education system in contemporary socialist environment, ideological and political education is to cultivate the ideological concept of college students ${ }^{[3]}$. Political point of view, the important class of ethics, through the planned, organized ideological and political education in colleges and universities, to train students correct world outlook and values of life, through the reform of ideological and political teaching methods in colleges and universities, the best mode of ideological and political education in colleges and universities is established, and the optimal selection and modeling of the mode of ideological and political education in colleges and universities are analyzed. To promote the improvement of the level of ideological and political education in colleges and universities, the selection mode of ideological and political education in colleges and universities can be divided into active education mode, passive education mode, vocational education mode, and so on. This paper analyzes the problems existing in ideological and political education in colleges and universities, analyzes the effectiveness of ideological and political education mode in colleges and universities by combining the teaching-driven mode, and optimizes the selection of ideological and political education models in colleges and universities. Cultivate a group of teachers who are not only good at theoretical teaching, but also good at solving students' practical problems and thinking puzzles, and establish an optimized mode of ideological and political teaching, so that ideological and political education can extend from a limited number of classes to an infinite number of extracurricular activities, so that ideological and political education work rooted in the daily life of college students ${ }^{[4]}$.

\section{Analysis on the orientation and importance of ideological and political education in colleges and universities}

Political education is the main content of the construction of spiritual civilization in China. Under the condition of socialist market economy, the pluralistic thinking is constantly presented. Through ideological and political education, the behavior and moral norms of college students and even the whole nation are regulated. To cultivate the benign moral quality of contemporary college students. Through ideological and political education, so as to cultivate students' correct values of life. The classroom of ideological and political education is an important classroom for the formation of life values. Ideological and political education is an important position in the construction of spiritual civilization in China [5].

Ideological and political education is the primary content of the construction of China's spiritual civilization and one of the main ways to solve social contradictions and problems. Ideological and political education is both very important and very difficult to do, especially under the conditions of a market economy. China's ideological and political work is relatively weak, and it is far from meeting the requirements of the development of modern society. There are many reasons for the lack of ideological and political work. But one of the important reasons is that we have neglected personality education and cultivation for a long time. I think that personality education is the foundation of ideological and political education ${ }^{[6]}$. Without this foundation, ideological and political education is like a duckweed without roots. It is always drifting on the surface of man's mind and cannot go deep.

The reason lies in: first, personality is the stable psychological basis for the formation of life values. Human values must be unified and stable, and this requires a person's psychological process and personality form to be unified and stable. Split personality can only produce split concept. 
Second, personality is the inner psychological basis for forming a particular world outlook and outlook on life ${ }^{[7]}$. The world outlook is the understanding of the world, although the correct world outlook comes from the correct theoretical guidance and study. But if there is no benign personality form as the internal psychological basis, it is difficult to inculcate external concepts. Third, personality is the main motive force for the formation of specific moral qualities. Personality has the characteristics of quality, so once personality is formed, People have the corresponding internal texture, different texture will adapt to different moral tendencies, benign personality is easy to establish benign moral quality. Of course, these basic functions of personality are not absolute, but often relative. At the same time, it also affects and transforms people's values, world outlook, outlook on life and moral consciousness. Therefore, personality has both unity and stability, as well as differentiation and variability. These characteristics also determine that benign personality is not easy to develop. In short, the state of personality can be said to be a subtle, implicit and primitive state of thought and morality, which is often developed, shaped and mature ${ }^{[8]}$.

\section{Main mode of ideological and political education in colleges and universities}

The optimal selection of ideological and political education mode in colleges and universities is constructed, so that the whole society really attaches importance to the ideological and moral construction of the society, we must really attach importance to the cultivation of citizens' personality. Families, schools and society should all see this. In the past, our ideological and political work was often devoted to positive, explicit education and external indoctrination, but rarely deepened ideological and political work from the perspective of personality and human psychology. The ideological and political work has lost its daily and subtle effects. Therefore, it is necessary to make a fundamental change in the methods of personality cultivation and ideological and moral education. The selection mode of ideological and political education in colleges and universities can be divided into active education mode, passive education mode, vocational education model, flipping classroom education model and micro-curriculum education model.

Ideological and political education is a science that guides people to form correct thought and behavior. It takes the law of people's thought and behavior to form and change, and the law of carrying out ideological and political education as their own research object. The change of viewpoint and standpoint, the formation law of world outlook and outlook on life are the focal points of the research. Ideological and political education is a complex network system, and its research objects are expressed as follows:

(1) Ideological and political education studies people's physiological and psychological factors, studies the development process of college students' thoughts, and reveals the development laws of college students' own thoughts and behaviors.

(2) Ideological and political education studies the universal relationship between college students' thoughts and outlook on life, the relationship between social factors and educational objects' outlook on life, the formation and development of the world outlook, and reveals and explores how to regulate the cross-three-dimensional role of social environment on educational objects, and the active role of the educational object when affected by the environment.

(3) The mode of ideological and political education in colleges and universities studies the management system and leading function of ideological and political education, the quality of ideological and political educators, how ideological and political education infiltrates into the field of business, and promotes society and schools. The problem that families cooperate with each other to form educational forces.

\section{Optimal selection of ideological and political Education and suggestions for Reform}

From the point of view of the cultivation of college students' personality and the way of ideological and political education, this paper puts forward several methods that should be paid attention to, in order to arouse people's thinking:

Firstly, it is necessary to combine external indoctrination with the development of human 
consciousness for personality education. From a sociological point of view, external indoctrination is the process of social education, and the process of human consciousness is an internal process. Only external indoctrination, instead of paying attention to how many personality elements and ideas are internalized by social individuals, the cultivation of personality is empty talk. Chinese traditional education attaches great importance to cultivating people's consciousness from an early age, and advocates the establishment of self-consciousness through cultivation. This is an effective method that we should learn from today.

Secondly, we must adopt the method of daily education so that the content of personality education and the daily life of people are closely integrated. And then form the habit of being human. The Chinese culture's education of "sweeping, coping, advancing and retreating" to children from an early age to cultivate their personality consciousness in terms of labor, speech and etiquette. Western society also attaches great importance to people's starting from an early age. Starting with small things, personality and moral character in everyday life is cultivated. For example, westerners pay attention to cultivating children's ability to live independently and reduce their dependence; teach children to love each other, care for the environment, and thus cultivate their love for their homes. We should actively absorb these good methods of education.

Thirdly, we must adopt the method of inductive education to avoid the adverse effect of compulsory education. The formation of personality should be natural. The same is true of moral cultivation. Educators should give priority to inducement and gradually lead the educated to establish a benign personality. Compulsory education is taken based on threats and sanctions against human beings and does not conform to people's respect and psychology. We should use it carefully. Forth, we must adopt the method of heuristic education so that the education mechanism can establish a benign personality under the condition of self-thinking.

In university education, students often regard teachers as the standard of life and the embodiment of society. The words and deeds of powerful people also imply that people around them: how people should live, how to work, how to be human. Visible, invisible education is often more effective than physical education, just as the nourishment of spring rain is often more beneficial to the growth of all things than the erosion of torrential rain. To achieve this, it depends on the high quality of the educator. In the end, the educator also has a constant education. This also shows that personality education is socialized, ideological and political education is socialized, and the formation of a good ideological and moral ethos in the whole society. It depends on the improvement of each person's personality and moral quality, as well as the mutual influence of each other.

Human thought and behavior is the result of the interaction between individual and environment. Social environment produces human needs, the needs produce human motivation, and motivation dominates human behavior. This kind of periodic movement, which reflects the interaction and restriction of various factors of thought, forms the process of people's ideological activity.

In the selection of the mode of ideological education in colleges and universities, we should follow the law of the formation and development of people's ideological behavior, and the ideological and political education should start with the actual performance of human beings, and analyze the ideological motives that dominate the action. Then analyze the objective external conditions under which the thought is generated from the ideological motivation, and then create and change the external environment according to the requirements of ideological and political education, so that it has the external conditions to produce good ideological motives. In order to encourage people to form good ideological motivation, and to help people adopt scientific methods to obtain the best possible results of action, such changes give rise to the objective external conditions needed, to grasp the needs of people, to change their motives, the process of controlling behavior is an important law of ideological and political education.

\section{Conclusions}

Under the new situation, ideological and political education in colleges and universities is facing great challenges and many problems, which cannot be ignored. The Chinese nation has a long 
history of five thousand years and a splendid culture. In educational activities, we should always persist in inheriting and carrying forward those outstanding historical and cultural traditions passed down from generation to generation and accumulated for a long time. In ideological and political education in colleges and universities, we should introduce advanced educational ideas and educational methods, and make full use of the new media. Innovating the ideological and political work platform, actively propagating mainstream culture, mainstream ideology, propagating socialist core values, helping students to form a correct outlook on life, values and world outlook, so that ideological and political education can be extended from limited class to unlimited extracurricular, and ideological and political education work can be rooted in the daily life of young students. In the selection of teaching methods, the reform of ideological and political education teaching should be explored with innovative thinking.

\section{References}

[1] Yang Shun, Chen Zhiguang, Xiao Nong. Implementation of directory index for Pmfs. Journal of Computer Applications, 2017, 37(5): 1241-1245.

[2] SEHGAL P, BASU S, SRINIVASAN K, et al. An empirical study of file systems on NVM[C]//Proceedings of the 201531st Symposium on Mass Storage Systems and Technologies. Piscataway, NJ: IEEE, 2015:1-14.

[3] SHA H M, CHEN X, ZHUGE Q, et al. Designing an efficient persistent in-memory file system[C]/Proceedings of the 2015 IEEE Non-Volatile Memory System and Applications Symposium. Piscataway, NJ: IEEE, 2015:1-6.

[4] Han Dezhi, CHEN Xuguang, LEI Yuxin, DAI Yongtao, ZHANG Xiao. Real-time data analysis system based on Spark Streaming and its application. Journal of Computer Applications, 2017, 37(5): 1263-1269.

[5] Li Xiao, GE Baozhen, LUO Qijun, LI Yunpeng, TIAN Qingguo. Acquisition of camera dynamic extrinsic parameters in free binocular stereo vision system. Journal of Computer Applications, 2017, 37(10): 2888-2894.

[6] MIORANDI D, SICARI S, PELLEGRINI F D,et al.Internet of things: vision, applications and research challenges[J].Ad Hoc Networks,2012,10(7):1497-1516.

[7] CHONG S K, GABER M M, KRISHNASWAMY S, et al. Energy conservation in wireless sensor networks: a rule-based approach[J]. Knowledge and Information Systems, 2011,2 8(3):579-614.

[8] OLIVEIRA L M, RODRIGUES J J. Wireless sensor networks: a survey on environmental monitoring[J]. Journal of Communications,2011,6(2):143-151. 